\begin{tabular}{|c|c|c|c|c|c|}
\hline ISRA (India) & $=3.117$ & SIS (USA) & $=0.912$ & ICV (Poland) & $=6.630$ \\
\hline ISI (Dubai, UAE & $=\mathbf{0 . 8 2 9}$ & РИНЦ (Russia) & $=0.156$ & PIF (India) & $=1.940$ \\
\hline GIF (Australia) & $=0.564$ & ESJI (KZ) & $=8.716$ & IBI (India) & $=4.260$ \\
\hline JIF & $=1.500$ & SJIF (Morocco) & $=5.667$ & OAJI (USA) & $=0.350$ \\
\hline
\end{tabular}

\section{SOI: $1.1 /$ TAS DOI: $10.15863 /$ TAS International Scientific Journal Theoretical \& Applied Science}

\author{
p-ISSN: 2308-4944 (print) e-ISSN: 2409-0085 (online) \\ Year: 2019 Issue: $04 \quad$ Volume: 72
}

Published: $23.04 .2019 \quad$ http://T-Science.org
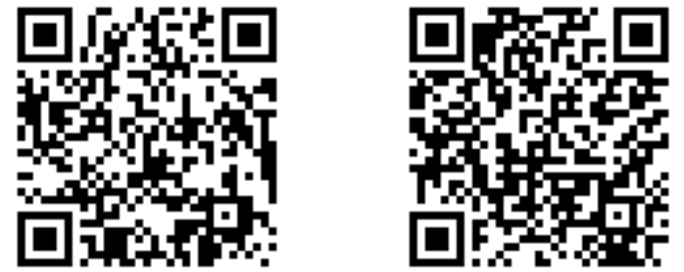

Sanavar Bazarbaevna Shadmanova doctor of historical sciences, professor,

Uzbekistan

Tuychi Adasevic Akhmedov senior lecturer of the Jizzakh state pedagogical Institute,

Uzbekistan

\title{
THE FUNCTIONAL TASKS OF TELEVISION IN THE CONTEXT OF GLOBALIZATION
}

\begin{abstract}
This article analyzes standing in front of the television function in the context of globalization. On this day, $T V$ is the most effective/influential form of media, having wide prevalence in the world. Therefore, it is important the use of its capabilities in the context of globalization. In particular, become increasingly important the creation of campaign materials, videos, TV shows, documentaries against such problems as drugs, AIDS, terrorism, drug trafficking, human trafficking and violation of ecology. On this day the world community is taking political, socioeconomic measures against these global problems. However, it is to be noted that the above measures is always effective. So, you need to pay attention to the use of such effective forms of prevention of global problems such as television and the Internet. Today there is a growing need not only to inform about global issues in the world, and in the preparation and broadcast of the analytical television programs aimed at preventing these problems.

Key words: media, television, globalization, terrorism, narcotics trafficking, human trafficking, mass culture, juvenile crime, Internet, TV show, movie, cartoon, series.

Language: Russian

Citation: Shadmanova, S. B., \& Akhmedov, T. A. (2019). The functional tasks of television in the context of globalization. ISJ Theoretical \& Applied Science, 04 (72), 283-286.

Soi: http://s-o-i.org/1.1/TAS-04-72-32 Doi: crossef https://dx.doi.org/10.15863/TAS.2019.04.72.32
\end{abstract}

\section{ФУНКЦИОНАЛЬНЫЕ ЗАДАЧИ ТЕЛЕВИДЕНИЯ В УСЛОВИЯХ ГЛОБАЛИЗАЦИИ}

Аннотация: в данной статье анализируется стоящие перед телевидением функции в условиях глобализации. На сей день телевидение является самым действенным/влиятельным видом средств массовой информации, имеющций широкую распространенность в мире. Поэтому является важным вопрос использования его возможности в условиях глобализаџии. В частности, становятся также все более актуальным создание агитационных материалов, видеороликов, телепередач, документальных фильмов против таких актуальных проблем как наркомания, СПИД, терроризм, наркобизнес, торговля людьми и нарушение экологии. На сей день мировая общественность предпринимает политические, социальноэкономические меры против этих глобальных проблем. Однако, нельзя отметить, что вышеназванные меры действует всегда эффективно. Значит, необходимо обратить внимание на использование от таких действенных видов предотвращения глобальных проблем как телевидение и интернет. Сегодня возрастает потребность не лишь в информировании о глобальных проблемах в мире, а в подготовке и трансляции аналитических телепередач, направленных на предотвращение этих проблем.

Ключевые слова: средства массовой информации, телевидение, глобализация, терроризм, наркоагрессия, торговля людьли, массовая культура, несовершеннолетние, преступность, Интернет, телепередача, кино, мультфильм, сериал.

\section{Введение}

В то же время телевидению придется брать на себя очень большую ответственность. Потому что телевидение является самым влиятельным видом средств массовой информации, имеющее аудиовизуальных возможностей. И на самом деле, на сей день телевидение выполняет кроме таких основных задач как удовлетворение потребности 


\begin{tabular}{|c|c|c|c|c|c|c|}
\hline \multirow{4}{*}{ Impact Factor: } & ISRA (India) & $=3.117$ & SIS (USA) & $=0.912$ & ICV (Poland) & $=6.630$ \\
\hline & ISI (Dubai, UAE & $=0.829$ & РИНЦ (Russia) & $=0.156$ & PIF (India) & $=1.940$ \\
\hline & GIF (Australia) & $=0.564$ & ESJI (KZ) & $=8.716$ & IBI (India) & $=4.260$ \\
\hline & JIF & $=1.500$ & SJIF (Morocco & $=5.667$ & OAJI (USA) & $=0.350$ \\
\hline
\end{tabular}

населения в получении объективной информации, содействие в их развлечение, а также, оно превратился в сильное средство, имеющее силу воздействия на психологию человека, расширения его кругозора и изменения его сознания [1.4.]. Так как телевидение предоставляет информацию быстрее, полноценнее, ближе к реальности и с эмоциональной окраской. Телезритель получает от любой передачи в определенной мере культурно-просветительскую пищу [2. 207-218.]. На сей день телевидение дает населению просветительское, моральное, эстетическое удовольствие и превратился в средство предоставления первичной информации, справки о какой-либо стране или происходящих событиях, размещения рекламы о предпринимательских субъектах, представителей шоу-бизнеса, прибыли для владельцев права на трансляцию видов массового спорта, в частности, футбола, бокса, волейбола и других, представления шедевров кино и театра широкой общественности [3].

\section{Основная часть}

Телевидение превратилось в редкую возможность для развития отношений между людьми, нациями, странами, религиями и цивилизациями. Потому что судьбы героев кино, их представления о будущем, реальности в них, стали играть важную роль в повседневной жизни людей. В буквальном смысле, люди начали верить в телевидение и его передачи, кино и мультфильмы [4]. Процесс глобализации оказал большое влияние на развитие спутниковых телеканалов. Трансляция различных фильмов и сериалов повысила популярность телевидения [5. 175-177.]. На сей день люди проводят перед телевизором в среднем по 2-3 часов в день. В Узбекистане телеканалы “Узбекистон”, “Ёшлар” и "Спорт" были и являются самыми крупными телеканалами. Согласно результатам проведенных опросов по данным телеканалам (2002-2006 гг.), в частности, на вопрос “В каких целях вы смотрите телеканал?” более 55\% респондентов ответили, “Для того, чтобы быть информированными о новостях и событиях, происходящих в мире и в нашей стране" [6. 195196.]. Значит, значительная часть времени, уделяемое населением для просмотра телевизора, расходуется на получение информации о событиях, происходящих в мире и в стране. Кроме того, в телеканалах Узбекистана регулярно транслируются ролики, направленные на предотвращение глобальных проблем. С 2007 года среди частных телеканалов проводятся конкурс самых лучших видеороликов, направленных на защиту окружающей среды [7. 27.], что является очень положительным опытом.

Теперь рассмотрим мировой опыт по борьбе против глобальных проблем.
В частности, каждый второй из наркозависимых лиц попали в сеть данной зависимости впоследствии обмана, принуждения, в силу непосредственного влияния других лиц. В докладе управления ООН по Наркотикам и преступности за 2014 год с озабоченностью отмечается широкое распространение наркотиков и прекурсов через сети интернет [8]. В 2015 году количество наркозависимых лиц привалило 500 миллионов человек, основную часть которых составила молодежь до 30 лет [9]. Статистические данные утверждают, что одно наркозависимое лицо может привлечь в наркозависимость в

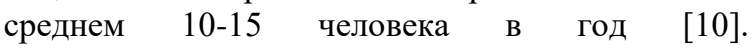
Положительный опыт по противодействию наркозависимости было проведено со стороны супруги Президента США Рональда Рейгана во время его президентства. Было проведено массовая кампания против потребления наркотических веществ. По телевидению было транслировано вред и отрицательные последствия наркотических веществ. К этим работам были привлечены многие общественные организации, знаменитости и известные специалисты страны. Они давали точную и понятную для общественность информацию о вреде наркотических веществ в организм человека. Телеканалы, рекламные бюро выделили бесплатное время для трансляции подобной агитации и пропаганды. В период до начала кампании количество молодых лиц, употребляющих наркотические вещества в США было наибольшим за всю историю страны. Среди лиц до 16 лет данный показатель составило до $50 \%$. В результате кампании в стране повысилось осведомленность общественности о воздействии и вреде наркотических веществ на здоровье и культурный облик человека, в обществе сформировался отрицательное отношение против наркотиков. В результате количество употребивших среди лиц до 16 лет уменьшилось до $30 \%$. Для сравнения приведем пример Швеции, где данный показатель составляет лишь 3\% [11].

ВИЧ также является глобальной проблемой. Озабоченный над этой глобализирующейся и получающий все более угрожающий вид проблемой Генеральная Ассамблея ООН провел три специальные сессии, посвященные только вопросу ВИЧ/СПИДа (июнь 2001 года, сентябрь 2003 года и июнь 2011 года), в которых определил направления противодействия к нему в мировом и региональных масштабах. На сей день отмечается, что телевидение является самым действенным средством в профилактике и предупреждении ВИЧ. В частности, в Узбекистане лишь в 2010 году было транслировано свыше 200 телепередач и радио слушаний о проблеме ВИЧ-инфекций. Подобный опыт дает свои плоды. Если в 2003 году лишь 34\% населения было проинформировано о 


\begin{tabular}{|c|c|c|c|c|c|c|}
\hline \multirow{4}{*}{ Impact Factor: } & ISRA (India) & $=3.117$ & SIS (USA) & $=0.912$ & ICV (Poland) & $=6.630$ \\
\hline & ISI (Dubai, UAE & $=0.829$ & РИНЦ (Russia & $=\mathbf{0 . 1 5 6}$ & PIF (India) & $=1.940$ \\
\hline & GIF (Australia) & $=0.564$ & ESJI (KZ) & $=8.716$ & IBI (India) & $=4.260$ \\
\hline & JIF & $=1.500$ & SJIF (Morocco & $=5.667$ & OAJI (USA) & $=0.350$ \\
\hline
\end{tabular}

профилактике ВИЧ-инфекции, то в 2009 году данный показатель возросло в два раза и составил 66,5\% [12. 59.].

Или возьмём, к примеру, вопрос борьбу против торговли людьми, который также становится все более актуальным. По всему миру от данного явления страдают все больше женщин и детей. Именно дети и женщины становятся жертвами торговли людьми. Одной из причин данной ситуации является неосведомленность женщин и детей о данном виде преступности. 30 июля 2014 года согласно принятому ООН резолюции впервые было отмечено день по борьбе против торговли людьми. Связи с этим бывший Генеральный секретарь ООН Пан Ги Мун в своем обращении призвал всех искоренению данную преступную практику, конфискации финансовых источников и активов преступников данного вида [13]. Согласно данным, в мире насчитывается свыше 27 млн. взрослых и 13 млн. детей, живущих в условиях рабства, что является самым многочисленным за всю историю человечества. Самые худшие примеры данного явления наблюдаются в таких странах как Непал, Судан, Индия, Габон и Гаити [14]. Специалисты утверждают, что важно и необходимо активизация пропаганду и агитацию в качестве одной из действенных мер по борьбе против торговли людьми. Исходя из этого, в некоторых странах подготавливаются телепередачи о торговле людьми как о самой опасной преступности, снимаются специальным фильмы. В частности, в Узбекистане также регулярно транслируются передачи и фильмы, направленные против торговле людьми.

На сей день по всему миру идут дискуссии о том, кому больше верят люди, Интернету или телевидению? Нельзя оспаривать то, что интернет на сей день распространяет больше информации чем другие виды СМИ. К примеру, согласно результатам опроса, проведенного в России $27 \%$ респондентов, отметили, что они получают информацию от сети Интернет. Даже среди граждан в возрасте 18-24 лет данный показатель составил $62 \%$. Однако $53 \%$ граждан считают, что информации из телевидения являются достоверным. Данный показатель по федеральным каналам России составил 75\% [15. 112.]. Значит, телевидение выделяется по сравнению с Интернетом своим достоверными информациями. На сей день кабельное и цифровое телевидение охватил весь мир. Вдобавок к этому Интернет также расширил свои возможности по трансляции телепередач по всему миру. Исходя из этого мировой общественности необходимо уделить внимание на применение/использование возможности телевидения для предотвращения наркомании, СПИДа, терроризма, наркобизнеса, торговли людьми и экологических проблем. На сей день по крупным телеканалам транслируются новости о глобальных проблемах, однако остается высоким потребность в повышении количества аналитических передач по предотвращению их.

\section{Заключение}

В условиях глобализации перед телевидением стоит нижеследующие задачи по предотвращению ряд проблем по всему миру:

- повышение количество телепередач, направленных на профилактику и предотвращение преступности и правонарушений среди несовершеннолетних лиц;

- проведение ежегодно по всему миру конкурсов видеороликов, направленных на защиту природы, предотвращению действий, наносящих ущерб окружающей среде, и трансляция этих роликов по сети Интернет;

- рассмотрение возможности телеканалов, имеющих высокий рейтинг по всему миру о трансляции фильмов, разоблачающих деятельность наркокартелей и преступных группировок по торговле людьми;

- подготовка и трансляция рекламных роликов против торговле людьми, незаконной трудовой миграции и других глобальных проблем;

- предупреждение широкую общественность о терроризме и его трагических последствиях путем трансляции аналитических передач;

- повышение количества просветительских передач по предотвращению отрицательных недугов, оказывающих влияние на воспитание молодежи и др.

\section{References:}

1. Khadzhaev, A. (2016). Uzbekiston milliy teleradiokompaniyasi: zamon bilan xamkadam. Tashkent: Uzbekiston.
2. Zhalilov, A. (2014). Zhamoatchilik nazoratini amalga oshirishda televideniening y̆rni/ OAV va zhamoatchilik nazoratiga doir davlat siesati. Tashkent: Akademiya. 


\begin{tabular}{|c|c|c|c|c|c|c|}
\hline \multirow{4}{*}{ Impact Factor: } & ISRA (India) & $=3.117$ & SIS (USA) & $=0.912$ & ICV (Poland) & $=6.630$ \\
\hline & ISI (Dubai, UAE & $=0.829$ & РИНЦ (Russia) & $=0.156$ & PIF (India) & $=1.940$ \\
\hline & GIF (Australia) & $=0.564$ & ESJI (KZ) & $=8.716$ & IBI (India) & $=4.260$ \\
\hline & JIF & $=1.500$ & SJIF (Morocco) & $=5.667$ & OAJI (USA) & $=0.350$ \\
\hline
\end{tabular}

3. (n.d.). Televidenie $v$ sisteme sredstv massovoy kommunikatsii. Retrieved 2019, from https://knowledge.allbest.ru/journalism/2c0a656 35a3bd68b5d43b89521206d27 0.html

4. (n.d.). Televidenie kak faktor globalizatsii. Retrieved 2019, from https://studopedia.ru/9 142339 televideniekak-faktor-globalizatsii.html

5. Golyadkin, N. A. (2011). Istoriya otechestvennogo $i$ zarubezhnogo televidenie. Moscow: ASPEKT PRESS.

6. Y̆taev, Ў. (2010). Televidenie - davr ky̆zgusi. Tashkent: Uzbekiston.

7. (2009). Ozod yurt ty̆lķinlari. Volny svobodnoy strany. The Wavas of a Free Country. Tashkent.

8. (2015). Global Drug Survey 2015: Ob"em narkotorgovli v Seti b'et sobstvennye rekordy. Retrieved 2019, from http://www.securitylab.ru/news/473232.php

9. (2015). Gazeta «Khalқ sy̆zi», ot 26 iyunya 2015 goda.

10. (n.d.). Blizkoe obshchenie s molodezh'yu. Retrieved 2019, from http://solzemli.ru/tyumen/aboutus/profy/pozitiv nyj-virus
11. (n.d.). Kak organizavat' effektivnuyu rabotu protiv narkotikov? Retrieved 2019, from http://www.narkotiki.ru/mir_5362.html

12. (2010). Uzbekiston Respublikasining Birinchi Prezidenti Islom Karimovning BMT sammitining Mingyillik rivozhlanish maķsadlariga bazishlangan yalpi mazhlisidagi nutқ̧ini

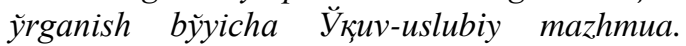
Tashkent.: Iқtisodiet.

13. (n.d.). Segodnya vpervye otmechaetsya Vsemirnyy den' bor'by s torgovley lyud'mi. Retrieved 2019, from http://un.by/print/news/world/83dcb5bc0d93d.h $\underline{\mathrm{tml}}$

14. (n.d.). Maloizvestnye fakty o sovremennoy rabotorgovle. Retrieved 2019, from http://1001facts.info/maloizvestnye-fakty-osovremennoj-rabotorgovle/\#more-2947

15. (n.d.). Opros: Televidenie ostaetsya dlya rossiyan glavnym istochnikom informatsii. www.mir24.tv/news/14355459/arestzamministra-kultury-pirumova-prodlen-do-15avgusta

16. Akhmedshina, F. (2016). Ommaviy tax̧didlar va eshlar ma"naviyati. Tashkent.: Yangi nashr. 